\title{
Ultrasound Measurement of Thyroid Isthmus Thickness in Clinically Euthyroid Subjects
}

\author{
Kayastha P, Paudel S, Ghimire RK \\ Department of Radiology and Imaging, Institute of Medicine, Tribhuvan University Teaching \\ Hospital, Kathmandu, Nepal
}

Received: September 18, 2018

Accepted: October 10, 2018

Published: December 30, 2018

Cite this paper:

Kayastha P, Paudel S, Ghimire RK. Ultrasound measurement of thyroid isthmus thickness in clinically euthyroid subjects. Nepalese Journal of Radiology 2018;8(12):26-29. https://doi.org/10.3126/njr.v8i2.22979

\begin{abstract}
Introduction: The purpose of this study was to establish the reference value of normal thickness of thyroid isthmus among clinically euthyroid Nepalese individuals using Ultrasonography and correlate this with thyroid volume, sex, individual's built and geographic location.
\end{abstract}

Methods: This was a prospective cross sectional study involving 485 clinically euthyroid individuals. B -mode Ultrasonography was used to measure the thickness of thyroid isthmus in transverse plane. Mean thickness of isthmus for male and female was obtained and Pearson correlation test was used to see the relationship with various factors.

Results: Among 485 individuals between 1 to 83 years of age, 221 were males and 264 were females. Maximum individuals $(72.99 \%)$ were from hilly region and minimum $(3.30 \%)$ were from Himalayan region. Mean thickness of isthmus was $3.097 \pm 1.009 \mathrm{~mm}$ (range 1.0 to 6.8 $\mathrm{mm})$. It was $3.114 \pm 0.9513 \mathrm{~mm}$ for male and $3.083 \pm 1.056 \mathrm{~mm}$ for female. Isthmus thickness best correlated with total thyroid volume $(\mathrm{r}=0.373, \mathrm{p}=0.0001)$. Isthmus thickness also positively correlated with body mass index $(r=0.355, \mathrm{p}=0.0001)$, body surface area $(\mathrm{r}=0.296, \mathrm{p}=0.0001)$, weight $(\mathrm{r}=0.334, \mathrm{p}=0.0001)$ and height $(\mathrm{r}=0.130, \mathrm{p}=0.004)$ of the individuals.

Conclusion: This study estimated the normal reference value of thyroid isthmus thickness. As isthmus thickness correlated well with total thyroid volume, it can roughly guide the thyroid volume and help assessment of thyroid size in diffuse thyroid disease.

Key words: Body Weight; Thyroid Diseases; Ultrasonography

\section{INTRODUCTION}

Thyroid is a suitable organ for the investigation with ultrasonography due to its superficial location in body. More over this modality is the sole modality that must be preferred

Correspondence to: Dr Prakash Kayastha Department of Radiology and Imaging Tribhuvan University Teaching Hospital Kathmandu, Nepal

Email: dr_prakash_kayastha@hotmail.com in diffuse thyroid diseases. ${ }^{1}$ The size and shape of the gland varies widely in normal individuals. Normally in tall individuals, the

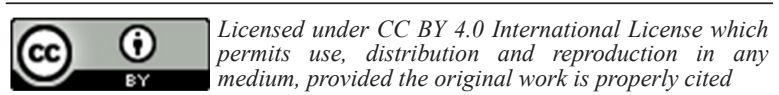


lobes have an elongated shape where as in shorter individuals they are oval. As a result, the normal dimensions of the gland have wide variability. ${ }^{2}$

The volume of the thyroid gland is an essential and one of the most important parameters evaluated in every ultrasound examination. It is useful in the diagnostic process and monitoring of thyroid diseases, especially the diffuse ones. ${ }^{3,4}$ The isthmus is a part of the thyroid gland not included in the sonographic assessment of the total thyroid volume. However, the isthmus consists of the same tissue as both lobes. For that reason, it should be visualized in each ultrasound examination of the thyroid gland and its thickness should be monitored. ${ }^{5}$ Ultrasound evaluation of the isthmus seems to be very useful in the diagnostic process and monitoring of thyroid diseases, especially the diffuse ones.

Many studies are published for the reference of normal thyroid volume. ${ }^{3,4,6,7,89}$ We have also published reference values of thyroid volume in clinically euthyroid Nepalese population. ${ }^{6}$ However, there are only few literatures published for the precise reference values of isthmus thickness and none of the literatures are from our region. This hinders an appropriate interpretation of the thyroid examination. Therefore, it is important to establish reference values for thyroid isthmus thickness for different demographic factors. So, we ultrsonographically studied the thyroid isthmus thickness in clinically euthyroid Nepalese population to establish the normal reference values and correlate this with sex, individual's built and geographic region.

\section{METHODS}

This was a prospective cross sectional study involving 485 individuals without any known thyroid disease or symptoms related to thyroid disease. The study was conducted in the Department of Radiology and Imaging, Tribhuvan University Teaching Hospital (TUTH) from September 2007 to August 2008. Patient who came for ultrasonography examination, for various reasons other than thyroid problems, were included in the study after obtaining informed consent. Detail information was recorded in the pre designed data collection sheet. Information included were particulars of the patients, history regarding thyroid symptoms, demographic location of the individual. Demographic location was assigned as per the division of country into Himalayan region, hilly region and Terai region. Patients' height in meters and weight in kilograms were recorded.

Body mass index (BMI) of the patient was obtained by using the formula:

$\mathrm{BMI}=$ weight in $\mathrm{Kg} /$ (height in $\mathrm{m})^{2}$

Body surface area (BSA) was obtained by using Mosteller formula:

$\operatorname{BSA}\left(\mathrm{m}^{2}\right)=($ height in $\mathrm{cm} x$ weight in $\mathrm{kg}) / 3600$

All the individuals were examined in the supine position with the neck hyperextended. Using a linear 7.5 MHz probe in SONOACE 8000 LIVE machine. The thyroid isthmus was measured in transverse scans. Thickness was measured antero-posteriorly in its thickest part. The volume of each thyroid lobe was calculated using the formula for a prolate ellipsoid,

Thyroid volume $=$ length $\mathrm{x}$ breadth $\mathrm{x}$ depth $\mathrm{x}$ ð/6.

Total thyroid volume was obtained by adding the volume of both the lobes. Volume of isthmus was not included in the total thyroid volume. Mean isthmus thickness was calculated for total sample and separately for different sex. Pierson correlation was used to see the relation of various demographic parameters with isthmus thickness. Independent t-test was used to calculate the significance between sex groups and different demographic groups.

\section{RESULTS}

The isthmus thickness was estimated in 485 individuals. Mean age was 34.06 years (range 1-83years). Out of 485 individuals, 221 individuals $(45.57 \%)$ were males and 264 individuals $(54.43 \%)$ were females. Among all 16 individuals $(3.30 \%)$ were from Himalayan region, 354 individuals $(72.99 \%)$ 
were from hilly region and 115 individuals $(23.71 \%)$ were from Terai. Mean thickness of isthmus was calculated for total sample and separately for male and females (Table 1). Mean thickness of isthmus was $3.097 \pm 1.009$ $\mathrm{mm}$ (range 1.0 to $6.8 \mathrm{~mm}$ ).

Table 1: Mean thickness of isthmus for different sex

\begin{tabular}{|c|c|c|c|}
\hline Categories & $\begin{array}{l}\text { Sample } \\
\text { size (n) }\end{array}$ & $\begin{array}{l}\text { Mean thickness } \\
(\mathrm{mm})\end{array}$ & $\begin{array}{l}\text { Standard } \\
\text { Deviation }\end{array}$ \\
\hline Male & 221 & 3.114 & 0.9513 \\
\hline Female & 264 & 3.083 & 1.056 \\
\hline Total & 485 & 3.097 & 1.009 \\
\hline
\end{tabular}

Mean thickness of isthmus was correlated with various demographic factors (Table 2). Isthmus thickness was significantly correlated with total thyroid volume. Significant positive correlation was also obtained with height, weight, body surface area and body mass index of the individuals. Isthmus thickness was not significantly different in different geological locations and different sex. Isthmus thickness was best correlated with total thyroid volume $(\mathrm{r}=0.373, \mathrm{p}<0.001)$.

\section{DISCUSSION}

We calculated the reference value for thyroid isthmus thickness in 485 clinically euthyroid individuals. We found mean thickness of thyroid isthmus as $3.114 \pm 0.9513 \mathrm{~mm}$ for male, $3.083 \pm 1.056 \mathrm{~mm}$ for female and 3.097 $\pm 1.009 \mathrm{~mm}$ (range 1.0 to $6.8 \mathrm{~mm}$ ) for total population. Our values are similar to that obtained by other authors. ${ }^{5,6}$ In a study done by Seker et $\mathrm{al}^{10}$ in 251 healthy volunteers in Turkey, mean isthmus thickness was $3.23 \pm 1$

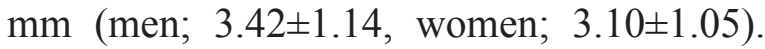

Kosiak et $\mathrm{al}^{5}$ studied thyroid isthmus thickness in 402 healthy children between 7 to 12 years of age from Poland. They proposed upper cut off value for normal isthmus thickness as 2.6 $\mathrm{mm}$ for male and $2.7 \mathrm{~mm}$ for female aged between 7-9 years, $3.3 \mathrm{~mm}$ for male and 3.5 $\mathrm{mm}$ for female aged between $10-12$ years.

In a study done by Sultana et $\mathrm{al}^{11}$ in 60 Bangladeshi cadavers, the mean \pm SD thickness of the isthmus of thyroid glands were $4.91 \pm 1.78 \mathrm{~mm}, 4.72 \pm 2.68 \mathrm{~mm}$ and $4.45 \pm 1.36 \mathrm{~mm}$ in three age groups $(<18$ years, $19-45$ years and $>45$ years) respectively \& the thickness of isthmus of thyroid gland was greater in 19-45 years group than other two groups. Slightly higher values in this study could be due to different characteristics of study groups (cadaveric study vs normal healthy individuals).

In the present study, isthmus thickness was significantly correlated with various body parameters including height, weight, body surface area and body mass index. Highest correlation was obtained with thyroid volume. This signifies that measurement of thyroid isthmus can roughly guide the thyroid volume, the most commonly used parameter for the assessment of thyroid size in diffuse thyroid disease. Similar correlations were also obtained in Seker et $\mathrm{al}^{10}$ study. In the present study, there was no significant sex difference in isthmus thickness. However, Seker et a ${ }^{10}$ found significant difference in isthmus thickness in two different sex, higher values were obtained for males $(p=0.021)$. We did not find any significant difference in isthmus thickness in various demographic locations of the individual.

Table 2: Correlation of isthmus thickness with various parameters

\begin{tabular}{|l|r|r|r|r|r|r|l|}
\hline & Height & BSA & BMI & Address & Sex & Weight & Volume \\
Pearson Correlation \\
$\begin{array}{l}\text { Significance (2-tailed) } \\
\text { Sample size (n) }\end{array}$ & $.130(*)$ & $.296(*)$ & $.355(* *)$ & -.029 & -.015 & $.334(*)$ & $.373(* *)$ \\
\cline { 2 - 9 } & .004 & .000 & .000 & .530 & .737 & .000 & .000 \\
\cline { 2 - 9 } & 485 & 485 & 485 & 485 & 485 & 485 & 485 \\
\hline
\end{tabular}

** Correlation is significant at the 0.01 level (2-tailed).

* Correlation is significant at the 0.05 level (2-tailed). 


\section{CONCLUSION}

We ultrasonographically measured the isthmus thickness in clinically euthyroid individuals. As isthmus thickness correlated well with total thyroid volume, it can roughly guide the thyroid volume and help assessment of thyroid size in diffuse thyroid disease.

\section{CONFLICT OF INTEREST}

None

\section{SOURCES OF FUNDING}

None

\section{REFERENCES}

1. Oğuz M, Aksungur EH, Bıçakçı YK, Çeliktaş M. Ultrasonography. Nobel Press 3. 1997.

2. Solbiati L, Charboneau JW, Reading CC, James EM, Hay ID. The Thyroid Gland. In: Rumack CM, Wilson CR, Charboneau JW, Levine D, editors. Diagnostic Ultrasound. 4th ed. Philadelphia: Mosby Inc; 2011.p.708-749

3. Miccoli P, Minuto MN, Orlandini C, Galleri D, Massi M, Berti P. Ultrasonography estimated thyroid volume: a prospective study about its reliability. Thyroid 2006;16(1):37-39. https://doi.org/10.1089/thy.2006.16.37

4. Semiz S, Şenol U, Bircan O, Gümüşlü S, Bilmen S, Bircan I. Correlation between age, body size and thyroid volume in an endemic area. $J$ Endocrinol Invest 2001;24(8):559-563. https://doi.org/10.1007/BF03343894

5. Kosiak W, Swięton D, Piskunowicz M, Kujawa M. Thyroid isthmus thickness in prepubertal healthy children in an iodine-sufficient region. Pol $J$ Radiol 2010;75(3): 17-19.
6. Kayastha P, Paudel S, Shrestha DM, Ghimire RK, Pradhan S. Study of thyroid volume by ultrasonography in clinically euthyroid patients. Journal of Institute of Medicine 2010;32(2):36-43. https://doi.org/10.3126/jiom.v32i2.4944

7. Berghout A, Wiersinga WM, Smits NJ, Touber JL. Determinants of thyroid volume as measured by ultrasonography in healthy adults in a non-iodine deficient area. Clinical Endocrinology 1987;26(3):273-280. https://doi.org/10.1111/j.1365-2265.1987. tb00784.x

8. Hegedus L, Perrild H, Poulsen LR et al. The determination of thyroid volume by ultrasound and its relationship to body weight, age, and sex in normal subjects. The Journal of Clinical Endocrinology \& Metabolism 1983;56(2):260-263. https://doi.org/10.1210/jcem-56-2-260

9. Rasmussen SN, Hjorth L. Determination of thyroid volume by ultrasonic scanning. $J$ Clin Ultrasound 1974;2(2):143-147. https://doi.org/10.1002/jcu.1870020211

10. Seker S, Tas I. Determination of Thyroid Volume and Its Relation with Isthmus Thickness. Eur $J$ Gen Med 2010;7(2):125-129. https://doi.org/10.29333/ejgm/82838

11. Sultana SZ, Khalil M, Khan MK et al. Morphometry of isthmus of thyroid gland in Bangladeshi cadaver. Mymensingh Med $J$ 2011;20(3):366-370. 